\title{
Cost-Effectiveness Analysis of Tisagenlecleucel in the Treatment of Relapsed or Refractory B-Cell Acute Lymphoblastic Leukaemia in Children and Young Adults in Spain
}

This article was published in the following Dove Press journal:

ClinicoEconomics and Outcomes Research

Josep Maria

Ribera Santasusana (iD)

Alejandra de Andrés Saldaña ${ }^{2}$

Nuria García-Muñoz ${ }^{3}$

Joana Gostkorzewicz ${ }^{2}$

Diana Martínez Llinàs ${ }^{3}$

Cristina Díaz de Heredia ${ }^{4}$

'Clinical Hematology Department,

Catalan Institute of Oncology - Hospital

Germans Trias i Pujol, Barcelona, Spain;

${ }^{2}$ Health Economics and Outcomes

Research, Novartis Farmacéutica S.A.,

Madrid, Spain; ${ }^{3}$ Oblikue Consulting, S.L.,

Barcelona, Spain; ${ }^{4}$ Paediatric Oncology

and Hematology Department -

Hematopoietic Stem Cell

Transplantation, Hospital Universitari Vall

d'Hebron, Barcelona, Spain
Correspondence: Diana Martínez Llinàs Oblikue Consulting, S.L., C/Comte d'Urgell, 240, 2-D, Barcelona 08036, Spain

Tel +3493252 I377

Fax +34937379984

Email diana.martinez@oblikue.com
Purpose: Tisagenlecleucel, a chimeric antigen receptor T-cell (CAR-T) therapy, is a promising alternative for the management of children and young adults with relapsed and refractory B-cell acute lymphoblastic leukemia ( $r / r$ ALL). The aim of this study was to determine whether treatment with tisagenlecleucel is a cost-effective intervention compared with salvage chemotherapy in paediatric and young adult patients with $\mathrm{r} / \mathrm{r}$ ALL in Spain.

Materials and Methods: A partitioned survival model of monthly cycles with three health states was used (event-free survival, progressive/relapsed disease and death). A lifetime time horizon and the Spanish National Health System perspective were adopted. During the first 5 years, permanence in the different health states was determined according to the results in the clinical studies. In successive years, mortality tables of the Spanish general population adjusted by standardized mortality rate for survivors of childhood cancer were used. Clinical, economic, and quality of life parameters were drawn from clinical trials and the literature. Only direct health costs (pharmacological costs and the costs derived from health resource use) were included. The robustness of the results was evaluated in a sensitivity analysis.

Results: This cost-effectiveness analysis showed a greater benefit (10.10 and 8.97 life-years gained [LYGs] and quality-adjusted life-years [QALYs] gained, respectively) and a higher cost ( $€ 258,378.40)$ for tisagenlecleucel compared to salvage chemotherapy. The resulting incremental cost-effectiveness and cost-utility ratios were $€ 25,576.80$ per LYG and $€ 28,818.52$ per QALY gained, respectively. In the sensitivity analysis, all the results were below $€ 50,000 /$ QALY. Conclusion: Tisagenlecleucel would represent a cost-effective intervention for the treatment of children and young adults with $\mathrm{r} / \mathrm{r}$ ALL in Spain.

Keywords: ALL, cost-effectiveness, tisagenlecleucel, acute lymphoblastic leukaemia, Spain, CAR-T

\section{Introduction}

Acute lymphoblastic leukaemia (ALL) is the most common neoplasm in children, accounting for $75-80 \%$ of cases of paediatric leukaemia and $25 \%$ of tumours diagnosed in children. ${ }^{1,2}$

In recent decades substantial improvements have occurred in the treatment of ALL, which have contributed to the cure rate rising from $<10 \%$ in the 1960 s to $>80 \%$ at present. ${ }^{3,4}$ However, refractory disease and relapse remain important challenges in the disease management. 
Between $15 \%$ and $20 \%$ of children and young adults with ALL are estimated to have refractory disease or relapses ( $\mathrm{r} / \mathrm{r}$ ALL) ${ }^{5-8}$ These patients have a very poor prognosis and the survival rate may be $<10 \%$ after two or more relapses. ${ }^{6}$

Children and young adults with $\mathrm{r} / \mathrm{r}$ ALL generally receive salvage chemotherapy to achieve complete remission (CR) and become candidates for allogeneic hematopoietic stem cell transplantation (HSCT), a potentially curative procedure. However, allogeneic HSCT is viable only in patients who respond to chemotherapy and have an adequate donor, ${ }^{9}$ and is associated with numerous potentially life-threatening short, medium- and long-term complications (infections, hepatic veno-occlusive disease, acute or chronic graft-versus-host disease) which have a substantial impact on the survival and the quality of life of patients. $^{10-12}$

Chimeric antigen receptor T-cell (CAR-T) therapies are a promising alternative for the management of children and young adults with $\mathrm{r} / \mathrm{r}$ ALL. CAR-T therapies are based on the genetic modification of the patient's lymphocytes in order to target and kill the tumour cells. CAR-T production requires the patient's lymphocytes to be extracted from the blood by apheresis and modified in the laboratory, adding a gene that codes for a chimeric antigen receptor (CAR). These modified and expanded cells are infused into the patient intravenously. ${ }^{13,14}$

Tisagenlecleucel is the first CAR-T therapy indicated for the treatment of paediatric and young adult patients up to 25 years of age with B-cell ALL that is refractory, in relapse post-transplant (HSCT) or in second or later relapse, and is the first gene therapy financed by the Spanish National Health System (NHS). ${ }^{14,15}$

The safety and efficacy of treatment with tisagenlecleucel in paediatric and young adult patients with $\mathrm{r} / \mathrm{r}$ B-cell ALL were evaluated in the pivotal ELIANA study and in two supportive studies (ENSIGN and B2101J). ${ }^{13,16-19}$ In the pivotal ELIANA study, among infused patients $(\mathrm{n}=$ 75), the overall remission rate within 3 months was $81.3 \%$, the median overall survival (OS) was 19.1 months, and the probability of survival at 6 and 12 months were $90.3 \%$ and $76.4 \%$, respectively. ${ }^{14,19}$ The most frequent adverse events (AE) of special interest were cytokine release syndrome (CRS) (77.3\%), infections (42.7\%), neurological events (40.0\%), cytopenias not resolved by day 28 (37.3\%), febrile neutropenia $(34.7 \%)$ and tumour lysis syndrome $(4.0 \%){ }^{19}$
The objective of this study was to determine whether treatment with tisagenlecleucel is a cost-effective intervention compared with salvage chemotherapy in paediatric and young adult patients with $\mathrm{r} / \mathrm{r}$ ALL within the indications supported by the Spanish NHS.

\section{Materials and Methods}

An economic evaluation of direct health costs was carried out from the perspective of the NHS using cost-effectiveness and cost-utility analyses.

We used a lifetime time horizon to capture all costs and benefits of the introduction of tisagenlecleucel. As recommended by national pharmacoeconomic guidelines when the time horizon of the analysis is $>1$ year, a discount rate of $3 \%$ per year was applied to costs and benefits. ${ }^{20,21}$

\section{Patients}

A population of paediatric and young adult patients up to 25 years of age with B-cell ALL that is refractory, in relapse post-transplant or in second or later relapse was considered. The definition of this population is consistent with the indication of tisagenlecleucel and the clinical characteristics of the population included in the ELIANA, ENSIGN and B2101J studies. ${ }^{13,16-19}$

\section{Treatments}

To date, the clinical studies of tisagenlecleucel have included a single arm, so there is no study comparing tisagenlecleucel with any other treatment. In the present analysis, tisagenlecleucel was compared with FLA-IDA salvage chemotherapy (combination of fludarabine, cytarabine and idarubicin), which is the most frequent treatment used in the target population of tisagenlecleucel in Spain.

In the case of tisagenlecleucel, we considered the results obtained in the intention to treat (ITT) population (all enrolled patients, regardless of whether they received tisagenlecleucel infusion or not) from the pooled data of the ELIANA (NCT02435849, cut-off date: December 31, 2017), ENSIGN (NCT02228096, cut-off date: October 6, 2017) and B2101J trials (NCT01626495, cut-off date: January 30,2017$).{ }^{13,16-19}$ In the case of the comparator, we considered the results of a study in which the efficacy of salvage chemotherapy was evaluated in children with $\mathrm{r} / \mathrm{r}$ $\mathrm{ALL},{ }^{22}$ a population comparable to that of patients eligible to receive tisagenlecleucel. 


\section{Analysis}

A partitioned survival model of monthly cycles with three health states was used: event-free survival (EFS), progressive/relapsed disease (PD/RL) and death. The model structure is shown in Figure 1. The proportion of patients in the EFS state is defined by the results of EFS with each treatment and corresponds to patients who are still free of progression. The proportion of patients in the $\mathrm{PD} / \mathrm{RL}$ state is defined by the difference between the OS and EFS curves, corresponding to patients who have relapsed or have progressed and who are still alive, and the proportion of patients in the death state is determined by the OS results.

\section{Effectiveness Measures}

Effectiveness was expressed as quality-adjusted life years (QALY) gained and life-years gained (LYG).

During the first 5 years, LYGs were estimated using parametric curves obtained from the OS results observed in the clinical studies (tisagenlecleucel: ELIANA, ENSIGN and B2101J; salvage chemotherapy: Von Stackelberg et al). ${ }^{13,16-19,22}$ Several models were constructed according to parametric functions (exponential, Weibull, Gompertz, log-normal, log-logistic, gamma) and spline curves (with one, two, three or four nodes). Given that no curve precisely matched the results observed, OS was estimated using a curve resulting from the weighting of the different distributions. Parametric estimates and goodness-of-fit criteria were estimated for each survival distribution (Table 1S). A visual comparison of the survival data based on the observed data, all considered distributions, and the weighted distribution are reported in Figure 1S (tisagenlecleucel) and Figure 2S (FLA-IDA).

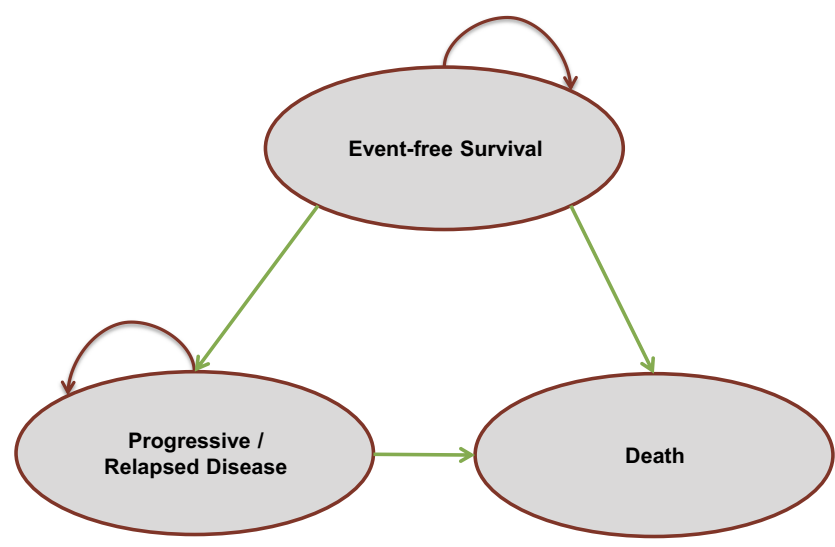

Figure I Structure of the cost-effectiveness model.
From the fifth year onwards, those who remained alive were subsequently assumed long-term survivors of ALL. The long-term ALL survival was modelled using mortality tables with a mortality adjustment using the standardized mortality rate (SMR) ratio of 5-year ALL survivors published in the literature. ${ }^{23}$ Therefore, LYG were estimated using mortality tables of the Spanish general population ${ }^{24}$ applying an SMR for survivors of childhood cancer (SMR $=9.05) .{ }^{23}$ The resulting OS curve is shown in Figure 2 .

During the first 5 years, EFS was estimated in different ways for tisagenlecleucel and for the comparator. For tisagenlecleucel, parametric curves models were fitted to the EFS data. For the comparator, no EFS data were available; therefore, the EFS curve was derived from the OS curve assuming that the cumulative hazard function for EFS would be proportional to the cumulative hazard function for OS (0.83). After year 5, the same approach was used for both treatments: the cumulative survival probabilities of EFS were assumed to flatten up until they reached OS (Figure 3).

QALYs were estimated according to the time patients remained in each health state and the utilities associated with that state, determined on a scale of 0 (death) to 1 (perfect health). The utilities in each health state were obtained from the literature ${ }^{25}$ and were validated by clinical experts. Additionally, disutilities associated with treatment, the intensive care unit (ICU) stay, and HSCT were considered, and an adjustment was applied according to age (Table 1). ${ }^{26,27}$

\section{Resource Use and Health Costs}

The cost estimate included the costs of pharmacological treatments and the costs derived from health resource use. All costs are expressed in 2018 euros.

In the case of tisagenlecleucel, it was assumed that all candidates for tisagenlecleucel infusion would undergo leukapheresis and cryopreservation of the patient leukapheresis material, but that only $81.8 \%$ would receive tisagenlecleucel infusion. ${ }^{16-19}$ Therefore, a different resource use was considered in the case of those who would receive tisagenlecleucel infusion and those who would not. In infused patients, based on the clinical trial results, the costs of the use of the following resources were considered: bridging chemotherapy (71.3\% of patients), ${ }^{16-19}$ lymphodepleting chemotherapy (96\% of patients), ${ }^{13,16}$ tisagenlecleucel infusion, ${ }^{13,16}$ hospitalization (Table 2), management of AE (Tables 2S, $\underline{3 \mathrm{~S}}$ and $\underline{4 S})$, HSCT $\left(16.58 \%\right.$ of patients), ${ }^{16-19}$ follow-up (Table 3) and terminal care. In non-infused patients, the 


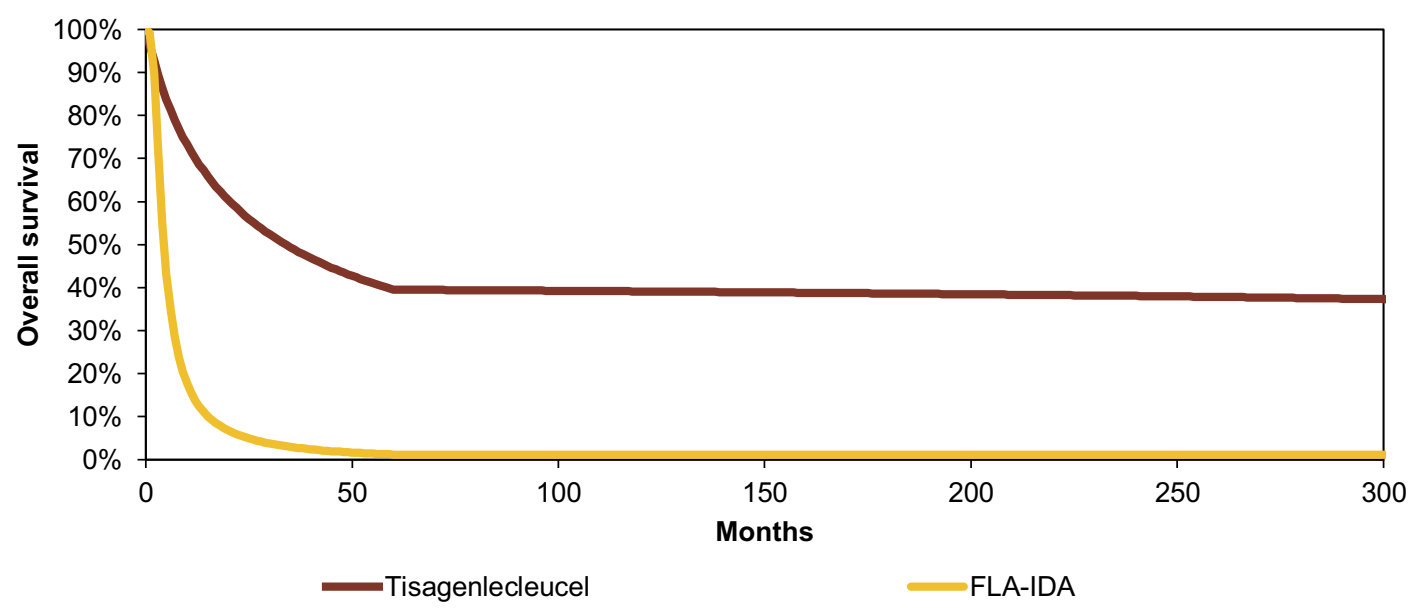

Figure 2 Predicted OS curve for tisagenlecleucel and salvage chemotherapy.

Abbreviation: FLA-IDA, combination of fludarabine, cytarabine and idarubicin; OS, overall survival.

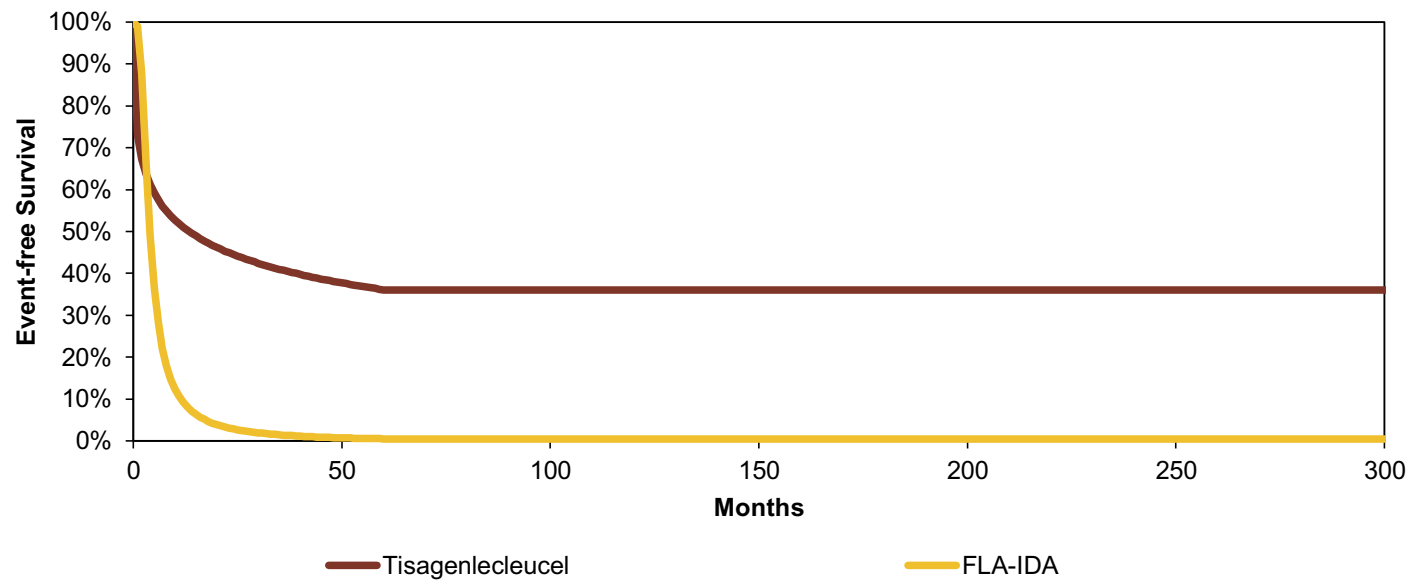

Figure 3 Predicted EFS curve for tisagenlecleucel and salvage chemotherapy.

Abbreviation: EFS, event-free survival; FLA-IDA, combination of fludarabine, cytaribine and idarubicin.

costs of salvage chemotherapy (one FLA-IDA cycle), hospitalization (Table 2), AE management (Table 2S), follow-up (Table 3) and terminal care were considered.

In the case of the comparator, the pharmacological costs of salvage chemotherapy (FLA-IDA), hospitalization costs (Table 2), costs of the management of AE (Table 2S), costs of HSCT (43.14\% of patients), ${ }^{22}$ follow-up (Table 3) and terminal care costs were considered.

The cost of treatment was estimated according to the exfactory price (EFP) of each drug in the database of the General Council of Official Associations of Pharmacists (CGCOF) after applying the corresponding discount according to Royal Decree Law (RDL) 8/2010 28,29 (Table 4).

The costs of treatment were calculated assuming wastage, and considering the therapeutic schedule in a patient with the baseline characteristics of the patients included in the ELIANA, ENSIGN and B2101J studies $\left(41.69 \mathrm{~kg}\right.$ and $\left.1.3 \mathrm{~m}^{2}\right)$. The treatment schedules and doses considered in the analysis were validated by clinical experts and are described in Table $5 .^{14}$

The unit costs of health resources were obtained from the literature and from national databases (Minimum Basic Data Set and eSalud) (Table 6). ${ }^{30-32}$

Finally, the costs derived from the management of grade III/IV AEs with an incidence of $\geq 5 \%$ in the two treatment options were considered. The AE rates of tisagenlecleucel were obtained from the ELIANA study and those of salvage chemotherapy from Raetz et al. ${ }^{13,16,19,33}$ Table 2S shows the AEs considered in the analysis, with the proportion of patients in both treatment arms and the 
Table I Utilities and Disutilities Considered in the Analysis

\begin{tabular}{|c|c|c|}
\hline \multicolumn{3}{|l|}{ Health State Utility } \\
\hline State & Utility & Source \\
\hline Utility in the EFS state & 0.91 & Based on Kelly et al, $2015^{25}$ \\
\hline Utility in the PD/RL state & 0.75 & \\
\hline \multicolumn{3}{|l|}{ Disutilities } \\
\hline Input & Disutility & Comments \\
\hline $\begin{array}{l}\text { Disutility associated with } \\
\text { treatment with } \\
\text { tisagenlecleucel or with } \\
\text { FLA-IDA }\end{array}$ & -0.42 & $\begin{array}{l}\text { Based on Sung et al, } 2003 .^{26} \\
\text { It was applied during the } \\
\text { hospital stay. }\end{array}$ \\
\hline $\begin{array}{l}\text { Disutility associated with } \\
\text { ICU stay }\end{array}$ & -0.91 & $\begin{array}{l}\text { It was assumed that during } \\
\text { hospitalization in the ICU } \\
\text { patients had a utility }=0 \text {. }\end{array}$ \\
\hline $\begin{array}{l}\text { Disutility associated with } \\
\text { HSCT }\end{array}$ & -0.57 & $\begin{array}{l}\text { Disutility based on Sung et al, } \\
2003 .^{26} \text { The disutility for } \\
\text { HSCT was assumed to last } \\
\text { for one year. }\end{array}$ \\
\hline \multicolumn{3}{|l|}{ Age-Related Utilities } \\
\hline Age (years) & Adjustment & Source \\
\hline Age $<25$ & I & Values based on Szende et al, \\
\hline Age $25-34$ & 0.99 & 2014 after adjustment for \\
\hline Age $35-44$ & 0.97 & each age range. ${ }^{27}$ \\
\hline Age $45-54$ & 0.90 & \\
\hline Age $55-64$ & 0.85 & \\
\hline Age $65-74$ & 0.83 & \\
\hline Age $75+$ & 0.77 & \\
\hline
\end{tabular}

Abbreviations: EFS, event-free survival; FLA-IDA, combination of fludarabine, cytarabine and idarubicin; HSCT, haematopoietic stem cell transplantation; ICU, intensive care unit; PD/RL, progressive/relapsed disease.

Table 2 Hospital Stay According to Treatment

\begin{tabular}{|c|c|c|}
\hline & $\begin{array}{l}\text { Number } \\
\text { of Days }\end{array}$ & Source \\
\hline \multicolumn{3}{|c|}{ Patients Infused with Tisagenlecleucel } \\
\hline $\begin{array}{l}\text { Lymphodepleting } \\
\text { chemotherapy }\end{array}$ & 13.98 days & $\begin{array}{l}\text { Estimate based on ELIANA; }{ }^{13,16} \\
\text { validated by clinical experts. }\end{array}$ \\
\hline Tisagenlecleucel & $\begin{array}{l}25.85 \\
\text { days }^{\mathrm{a}} \\
\mathrm{I} .78 \text { days } \\
\text { in } \mathrm{ICU}^{\mathrm{b}}\end{array}$ & $\begin{array}{l}\text { Estimate based on ELIANA; }{ }^{13,16} \\
\text { validated by clinical experts. }\end{array}$ \\
\hline \multicolumn{3}{|c|}{ Patients Treated with Salvage Chemotherapy } \\
\hline FLA-IDA & 21 days & $\begin{array}{l}\text { Based on opinion of clinical } \\
\text { experts }\end{array}$ \\
\hline
\end{tabular}

Notes: ${ }^{a}$ Average length of stay after tisagenlecleucel infusion (excluding ICU). ${ }^{b}$ Average days of ICU stay not due to CRS after tisagenlecleucel infusion. Abbreviations: FLA-IDA, combination of fludarabine, cytarabine and idarubicin; $\mathrm{ICU}$, intensive care unit. unit cost. The costs of AEs were obtained from the literature and the eSalud database. ${ }^{32}$

Additionally, in patients treated with tisagenlecleucel, the costs of treatment with intravenous immunoglobulin (IVIG) during the duration of B-cell aplasia recorded in the ELIANA study were collected, considering that $73.33 \%$ of infused patients would receive IVIG for 11.4 months, resulting in a cost per event of $€ 12,775.99$ (see detail in the supplementary material Table 4S) ${ }^{13,16,34}$

\section{Sensitivity Analysis}

A deterministic sensitivity analysis was performed to confirm the robustness of the model and evaluate the influence of variations in the parameters with the greatest uncertainty. As recommended by the main Spanish pharmacoeconomic guidelines, discount rates of $0 \%$ and $5 \%$ were applied for costs and benefits, and the effect of modifications in the time horizon (20 and 50 years, compared with the lifetime horizon in the base case) was evaluated. ${ }^{20,21}$ Additionally, the effect of variations in different parameters was evaluated, including, among others, variations in the length of IVIG treatment (EFS; versus 11.4 months in the base case), the point from which long-term ALL survival data for OS are considered (after 2 years vs 5 years in the base case), the estimated efficacy based on alternative parametric functions, the utilities considered (ELIANA; versus the estimate based on the literature in the base case), the proportion of transplanted patients, and the unit costs of all resources considered in the model $( \pm 25 \%)$. The details of the analysis are shown in the supplementary material (Tables 5S and $\underline{6 \mathrm{~S}}$ ).

\section{Results}

\section{Results of the Base Case}

The addition of tisagenlecleucel to the treatment of patients aged up to 25 years with $\mathrm{r} / \mathrm{r}$ ALL provided an additional gain in effectiveness over salvage chemotherapy of 10.10 LYGs and 8.97 QALYs (Table 7).

The introduction of tisagenlecleucel entailed an additional total cost of $€ 258,378.40$. In the case of tisagenlecleucel, the main cost determinant was the pharmacological cost while, in the case of FLA-IDA, it was the cost derived from HSCT (Table 7).

Taking these results into account, an incremental costeffectiveness ratio (ICER) of $€ 25,576.80 / \mathrm{LYG}$ and an incremental cost-utility ratio (ICUR) of $€ 28,818.52 /$ QALY was estimated. 
Table 3 Resource Use of Tisagenlecleucel and Salvage Chemotherapy in EFS and PD/RL States

\begin{tabular}{|c|c|c|c|c|c|c|}
\hline & & \multicolumn{4}{|c|}{ Frequency of Visits/Tests in the EFS State } & \multirow[t]{2}{*}{ PD/RL } \\
\hline & & Year I & Year 2 & Years 3-5 & Years 5+ & \\
\hline Consultant visit & $\begin{array}{l}\text { Tisagenlecleucel } \\
\text { Salvage chemotherapy }\end{array}$ & $\begin{array}{l}12 \\
6\end{array}$ & 4 & 2 & $\begin{array}{l}2 \\
1\end{array}$ & 6 \\
\hline Blood tests & $\begin{array}{l}\text { Tisagenlecleucel } \\
\text { Salvage chemotherapy }\end{array}$ & $\begin{array}{l}16 \\
6\end{array}$ & 4 & 2 & 0 & 6 \\
\hline Cerebrospinal fluid & $\begin{array}{l}\text { Tisagenlecleucel } \\
\text { Salvage chemotherapy }\end{array}$ & $\begin{array}{l}1 \\
1\end{array}$ & 0 & 0 & 0 & 1 \\
\hline Electrocardiogram & $\begin{array}{l}\text { Tisagenlecleucel } \\
\text { Salvage chemotherapy }\end{array}$ & $\begin{array}{l}1 \\
0\end{array}$ & 0 & 0 & 0 & 0 \\
\hline Bone marrow aspirate & $\begin{array}{l}\text { Tisagenlecleucel } \\
\text { Salvage chemotherapy }\end{array}$ & $\begin{array}{l}3 \\
1\end{array}$ & 0 & 0 & 0 & 1 \\
\hline Bone marrow biopsy & $\begin{array}{l}\text { Tisagenlecleucel } \\
\text { Salvage chemotherapy }\end{array}$ & $\begin{array}{l}3 \\
0\end{array}$ & 0 & 0 & 0 & 0 \\
\hline Echocardiogram & $\begin{array}{l}\text { Tisagenlecleucel } \\
\text { Salvage chemotherapy }\end{array}$ & $\begin{array}{l}0 \\
1\end{array}$ & 0 & 0 & 0 & 1 \\
\hline
\end{tabular}

Notes: Resource use validated by clinical experts.

Abbreviations: EFS, event-free survival; PD/RL, progressive/relapsed disease.

Table 4 Drug Prices Before and After the Discount According to RDL 8/2010

\begin{tabular}{|c|c|c|c|}
\hline Treatment & EFP & Discount RDL 8/20I0 & EFP - Discount RDL 8/2010 \\
\hline Tisagenlecleucel ( $1.2 \times 10^{6}$ to $6 \times 10^{8}$ cells dispersion for infusion $)$ & $€ 320,000.00$ & $4 \%$ & $€ 307,200.00$ \\
\hline Cyclophosphamide (I g, I vial) & $€ 10.40$ & $15 \%$ & $€ 8.84$ \\
\hline Etoposide $(20 \mathrm{mg} / \mathrm{mL}$, I vial, $5 \mathrm{~mL})$ & $€ 5.03$ & - & $€ 5.03$ \\
\hline Fludarabine $(25 \mathrm{mg} / \mathrm{mL}$, I vial, $2 \mathrm{~mL})$ & $€ 49.77$ & - & $€ 49.77$ \\
\hline Cytarabine (I g, I vial, $10 \mathrm{~mL})$ & $€ 14.38$ & - & $€ 14.38$ \\
\hline Idarubicin (5 mg, I vial, $5 \mathrm{~mL}$ ) & $€ 40.90$ & - & $€ 40.90$ \\
\hline
\end{tabular}

Abbreviations: EFP, ex-factory price; RDL, royal decree Law.

In short, the results of this analysis show that tisagenlecleucel would be a cost-effective intervention compared with salvage chemotherapy, considering a willingness-topay threshold of $€ 30,000 /$ QALY.

\section{Results of the Sensitivity Analysis}

The sensitivity analysis showed that the results of the model are robust, since all variations result in an ICUR below $€ 50,000$ /QALY. The details of all the results are shown in the supplementary material (Tables $5 \mathrm{~S}$ and $\underline{6 \mathrm{~S}}$ ).

In the tornado diagram (Figure 4), the changes in parameters that most affected the results were those made in the discount rate for costs and benefits $(0-5 \% ; 3 \%$ base case), the pharmacological cost of tisagenlecleucel $( \pm 25 \%)$ and age of onset (1-25 years; 12 years base case). Even so, all modifications resulted in an ICUR below $€ 40,000$ /QALY.
In the analysis of scenarios (Table 6S in the supplementary material), the modification of the time horizon (20 years; vs lifetime in the base case) and different OS parametric functions are the most influential variations in the results, in all cases resulting in an ICUR below $€ 50,000$ /QALY.

\section{Discussion}

The therapeutic value of tisagenlecleucel in patients with $\mathrm{r} / \mathrm{r}$ ALL has been widely recognized by the health systems of various European Union countries, including Spain, which NHS has incorporated tisagenlecleucel into its portfolio of services at unprecedented speed for a high-cost, high-complexity treatment. ${ }^{15,35}$

To date, three economic evaluations of tisagenlecleucel for the treatment of paediatric $r / r$ ALL have been carried out, all in the United States and from the perspective of the health service 
Table 5 Treatment Dosages Considered in the Model

\begin{tabular}{|c|c|c|c|}
\hline \multicolumn{2}{|l|}{ Treatment } & Drug & Dosage $^{a}$ \\
\hline \multicolumn{4}{|c|}{ Intervention Treatment: Tisagenlecleucel } \\
\hline \multirow{4}{*}{$\begin{array}{l}\text { Lymphodepleting } \\
\text { chemotherapy }^{\mathrm{b}}\end{array}$} & \multirow[t]{2}{*}{ Regimen I } & Fludarabine & $30 \mathrm{mg} / \mathrm{m}^{2}$ IV daily for 4 days \\
\hline & & Cyclophosphamide & $500 \mathrm{mg} / \mathrm{m}^{2}$ IV daily for 2 days \\
\hline & \multirow[t]{2}{*}{ Regimen 2} & Cytarabine & $500 \mathrm{mg} / \mathrm{m}^{2}$ IV daily for 2 days \\
\hline & & Etoposide & $150 \mathrm{mg} / \mathrm{m}^{2}$ IV daily for 3 days \\
\hline CAR-T infusion & & Tisagenlecleucel & $\begin{array}{l}\text { For patients } 50 \mathrm{~kg} \text { and below: } 0.2 \text { to } 5 \times 10^{6} \mathrm{CAR} \text {-positive viable T cells } / \mathrm{kg} \\
\text { body weight. } \\
\text { For patients above } 50 \mathrm{~kg}: 0.1 \text { to } 2.5 \times 10^{8} \text { CAR-positive viable T cells (non- } \\
\text { weight based). }\end{array}$ \\
\hline \multicolumn{4}{|c|}{ Comparator Treatment: Salvage Chemotherapy } \\
\hline \multicolumn{2}{|l|}{ FLA-IDA } & $\begin{array}{l}\text { Fludarabine } \\
\text { Cytarabine } \\
\text { Idarubicin }\end{array}$ & $\begin{array}{l}30 \mathrm{mg} / \mathrm{m}^{2} \text { IV daily ( } 5 \text { doses) } \\
2,000 \mathrm{mg} / \mathrm{m}^{2} \text { IV daily ( } 5 \text { doses) } \\
8 \mathrm{mg} / \mathrm{m}^{2} \text { IV daily ( } 3 \text { doses) }\end{array}$ \\
\hline
\end{tabular}

Notes: ${ }^{\text {a}}$ Dosages validated by clinical experts. ${ }^{\mathrm{b}}$ Based on the ELIANA study, it was considered that $94.67 \%$ of patients received regimen I; and I.33\% of patients, regimen $2 .{ }^{13,14}$ Abbreviations: CAR, chimeric antigen receptor; FLA-IDA, combination of fludarabine, cytarabine and idarubicin; IV, intravenous.

payer. $^{36-38}$ Additionally, a report by the National Institute for Health and Care Excellence (NICE) recommended the use of tisagenlecleucel for paediatric $\mathrm{r} / \mathrm{r}$ ALL within the Cancer

Table 6 Unit Costs of Health Resources Used in the Analysis

\begin{tabular}{|c|c|}
\hline Resources & Unit Cost \\
\hline \multicolumn{2}{|l|}{ Hospitalizations } \\
\hline General hospitalization (haematology) (cost/day) ${ }^{\mathrm{a}}$ & $€ 915.72$ \\
\hline ICU stay (cost/day) & $€ 1,470.36$ \\
\hline \multicolumn{2}{|l|}{ Other Health Resources } \\
\hline Cryopreservation & $€ \mathrm{I}, 109.35$ \\
\hline Leukapheresis & $€ \mathrm{I}, 640.58$ \\
\hline Day hospital visit & $€ 220.90$ \\
\hline Specialist visit & $€ 86.46$ \\
\hline Electrocardiogram & $€ 40.12$ \\
\hline Blood tests & $€ 99.51$ \\
\hline Cerebrospinal fluid & $€ 317.85$ \\
\hline Bone marrow aspirate & $€ 280.42$ \\
\hline Echocardiogram & $€ 102.68$ \\
\hline Bone marrow biopsy & $€ 280.42$ \\
\hline Subsequent HSCT cost ${ }^{b}$ & $€ 88,237.91$ \\
\hline Terminal care $\operatorname{coss}^{c}$ & $€ 6,041.74$ \\
\hline
\end{tabular}

Notes: ${ }^{a}$ Estimated from the cost of the stay equivalent to DRGICD-9-CM 204 "Lymphoid leukaemia" and the length of stay for this ICD-9-CM stipulated in the Minimum Basic Data Set (CMBD). ${ }^{31}$ b The costs of HSCT include: cost of allogeneic HSCT process (Cost 803-ALOGENIC BONE MARROW TRANSPLANTATION); cost of resource use resulting from obtaining hematopoietic stem cells (weighted according to the sources of hematopoietic stem cells, based on data from the Annual Report on HSCT of the National Transplant Organization); and cost of follow-up for 2 years. Details of the estimate pending publication. ${ }^{C}$ Estimated from: Nuño-Solinís et al. ${ }^{30}$

Abbreviations: $\mathrm{HSCT}$, hematopoietic stem cell transplantation; $\mathrm{ICU}$, intensive care unit.
Drugs Fund ${ }^{39}$ and a report from the Institute for Clinical and Economic Review concluded that tisagenlecleucel could be cost-effective in this indication. ${ }^{40}$ In these evaluations, tisagenlecleucel was compared with blinatumomab, ${ }^{38,39}$ and with salvage chemotherapy based on the use of clofarabine monotherapy ${ }^{37,40}$ or other agents. ${ }^{36,38}$

The present study is the first cost-effectiveness and cost-utility analysis of tisagenlecleucel in a European country. Our results show that treatment with tisagenlecleucel would be a cost-effective intervention compared with salvage chemotherapy in paediatric and young adult patients with $\mathrm{r} / \mathrm{r}$ ALL in Spain, providing a gain of 9.03 QALYs and an ICUR below $€ 30,000 /$ QALY, a cost-utility threshold commonly accepted in Spain. ${ }^{21,41}$ Likewise, the introduction of tisagenlecleucel would also be associated with an incremental gain of 10.10 LYGs, with an ICER of $€ 25,576.80 / \mathrm{LYG}$.

Although the QALYs gained in the present study are similar to those estimated by Whittington et $\mathrm{al}^{37}$ and Sarkar et $\mathrm{al},{ }^{36}$ and somewhat lower than those found by Lin et al, ${ }^{38}$ the ICUR estimated in this study from the NHS perspective ( $€ 28,818.52$ / QALY) is clearly lower than that observed in the previous reports. This could be due, mainly, to the fact that the difference in the price of tisagenlecleucel between Spain and the US is more than $€ 200,000$. Likewise, comparisons between our study and the US economic evaluations should be made with caution, due to differences in the methodologies used and the variability inherent to carrying out analyses in different settings. 
Table 7 Results of the Cost-Effectiveness and Cost-Utility Analysis. Base Case

\begin{tabular}{|c|c|c|c|}
\hline & $\begin{array}{l}\text { Tisagenle- } \\
\text { cleucel }\end{array}$ & FLA-IDA & Incremental \\
\hline \multicolumn{4}{|l|}{ Costs } \\
\hline $\begin{array}{l}\text { Pre-treatment }^{\mathrm{a}} \\
\text { Treatment } \\
\text { Drug } \\
\text { Hospitalization } \\
\text { Adverse events } \\
\text { Follow-up } \\
\text { EFS } \\
\text { PD/RL } \\
\text { Subsequent HSCT } \\
\text { Terminal care } \\
\text { Total costs }\end{array}$ & $\begin{array}{l}€ 27,694.64 \\
€ 276,381.25 \\
€ 251,378.83 \\
€ 25,002.42 \\
€ 31,244.21 \\
€ 5,978.91 \\
€ 4,415.65 \\
€ 1,563.25 \\
€ 11,964.46 \\
€ 4,161.61 \\
€ 357,425.07\end{array}$ & $\begin{array}{l}- \\
€ 20,062.68 \\
€ 832.65 \\
€ 19,230.03 \\
€ 34,098.83 \\
€ 869.07 \\
€ 473.25 \\
€ 395.82 \\
€ 38,063.41 \\
€ 5,952.68 \\
€ 99,046.67\end{array}$ & $\begin{array}{l}€ 27,694.64 \\
€ 256,318.57 \\
€ 250,546.18 \\
€ 5,772.39 \\
€-2,854.61 \\
€ 5,109.83 \\
€ 3,942.40 \\
€ 1,167.43 \\
€-26,098.95 \\
€-1,791.07 \\
€ 258,378.40\end{array}$ \\
\hline \multicolumn{4}{|l|}{ Effectiveness } \\
\hline $\begin{array}{l}\text { LYGs } \\
\text { EFS } \\
\text { PD/RL }\end{array}$ & $\begin{array}{l}10.97 \\
10.05 \\
0.92\end{array}$ & $\begin{array}{l}0.87 \\
0.62 \\
0.25\end{array}$ & $\begin{array}{l}10.10 \\
9.43 \\
0.67\end{array}$ \\
\hline $\begin{array}{l}\text { QALYs } \\
\text { EFS } \\
\text { PD/RL }\end{array}$ & $\begin{array}{l}9.43 \\
8.86 \\
0.69\end{array}$ & $\begin{array}{l}0.46 \\
0.56 \\
0.19\end{array}$ & $\begin{array}{l}8.97 \\
8.30 \\
0.50\end{array}$ \\
\hline $\begin{array}{l}\text { ICER (€ per LYG): } \\
\text { ICUR (€ per QALY } \\
\text { gained): }\end{array}$ & \multicolumn{3}{|l|}{$\begin{array}{l}€ 25,576.80 \\
€ 28,818.52\end{array}$} \\
\hline
\end{tabular}

Notes: ${ }^{2}$ The cost of pre-treatment includes the cost of bridging chemotherapy, lymphodepleting chemotherapy and the costs of hospitalization for bridging chemotherapy and lymphodepleting chemotherapy. ${ }^{\text {b}}$ The costs of HSCT include: cost of allogeneic HSCT (Cost 803-ALOGENIC BONE MARROW TRANSPLANTATION); cost of resource use resulting from obtaining hematopoietic stem cells (weighted according to the sources of hematopoietic stem cells, based on data from the Annual Report on HSCT of the National Transplant Organization); and cost of follow-up for 2 years. Details of the estimate pending publication. The figures in bold represent subtotals and totals.

Abbreviations: EFS, event-free survival; FLA-IDA, combination of fludarabine, cytarabine and idarubicin; HSCT, haematopoietic stem cell transplantation; ICER, incremental cost-effectiveness ratio; ICUR, incremental cost-utility ratio; LYG, life year gained; PD/RL, progressive/relapsed disease; QALY, quality-adjusted life year.

In the previous reports, the costs and results of tisagenlecleucel were considered on the assumption that all patients received the tisagenlecleucel infusion (per-protocol population analysis). However, in the present study, costs and efficacy results were considered in the candidate population to receive tisagenlecleucel, which includes both infused and non-infused patients (ITT population analysis), taking into account the results observed in clinical trials. Considering the clinical and economic results in the ITT population reflects a more realistic approach to the results expected in clinical practice, and was the option recommended by clinical experts.
Currently, in Spain, patients with $\mathrm{r} / \mathrm{r}$ ALL receive salvage chemotherapy in order to achieve a $\mathrm{CR}$ that allows HSCT and, therefore, this therapeutic intervention has been considered as the comparator. However, in clinical practice, a high proportion of patients treated with salvage chemotherapy do not achieve CR, do not have a compatible donor, die before being able to receive HSCT or develop complications during salvage chemotherapy that contraindicate the HSCT realization. For this reason, in the cost estimates of the comparator, the proportion of patients receiving HSCT observed in the same study that was used as a source of effectiveness data was considered. ${ }^{22}$ Likewise, as the rate of transplantation observed in the clinical trials of tisagenlecleucel (16.58\%) was considered, the present study provides a view closer to real clinical practice than previous reports. ${ }^{37,38}$ In any case, the sensitivity analysis of the present study showed that neither variations in the proportion of transplanted patients or the cost of HSCT had a significant impact on the results.

In the cost-effectiveness study conducted by Lin et al, ${ }^{38}$ the efficiency of tisagenlecleucel was based on confirmation of the long-term effectiveness results without the requirement for HSCT in a substantial proportion of patients. However, in the present analysis, considering that $16.58 \%$ of patients treated with tisagenlecleucel would receive HSCT, tisagenlecleucel would remain a cost-effective option. Likewise, to assess the effect of variations on the proportion of transplanted patients, in the sensitivity analysis a range in HSCT carried out of between $11.33 \%$ and $21.83 \%$ was considered. In all cases, the results were below $€ 30,000 / \mathrm{QALY}$.

In economic evaluations in other countries, tisagenlecleucel was compared with blinatumomab and clofarabine monotherapy. ${ }^{37-39}$ However, these options would not be adequate in our setting. Blinatumomab has a negative financing opinion ${ }^{42,43}$ and, in the opinion of clinical experts, clofarabine monotherapy is not considered a treatment option for these patients in Spain. Therefore, conservatively, we chose to estimate the costs of salvage chemotherapy based on FLA-IDA, the most frequent salvage chemotherapy used in Spain.

However, in some patients, blinatumomab might be used as a foreign drug, which would mean a significant increase in pharmacological costs for the comparator, with a modest effect in terms of efficacy. In children with $\mathrm{r} / \mathrm{r}$ ALL, blinatumomab has shown a response rate ${ }^{44-47}$ somewhat higher than that observed with salvage chemotherapy ${ }^{15,19,48}$ but lower than that observed with tisagenlecleucel in the ELIANA study (81.3\% at 3 months). ${ }^{14,19}$ 


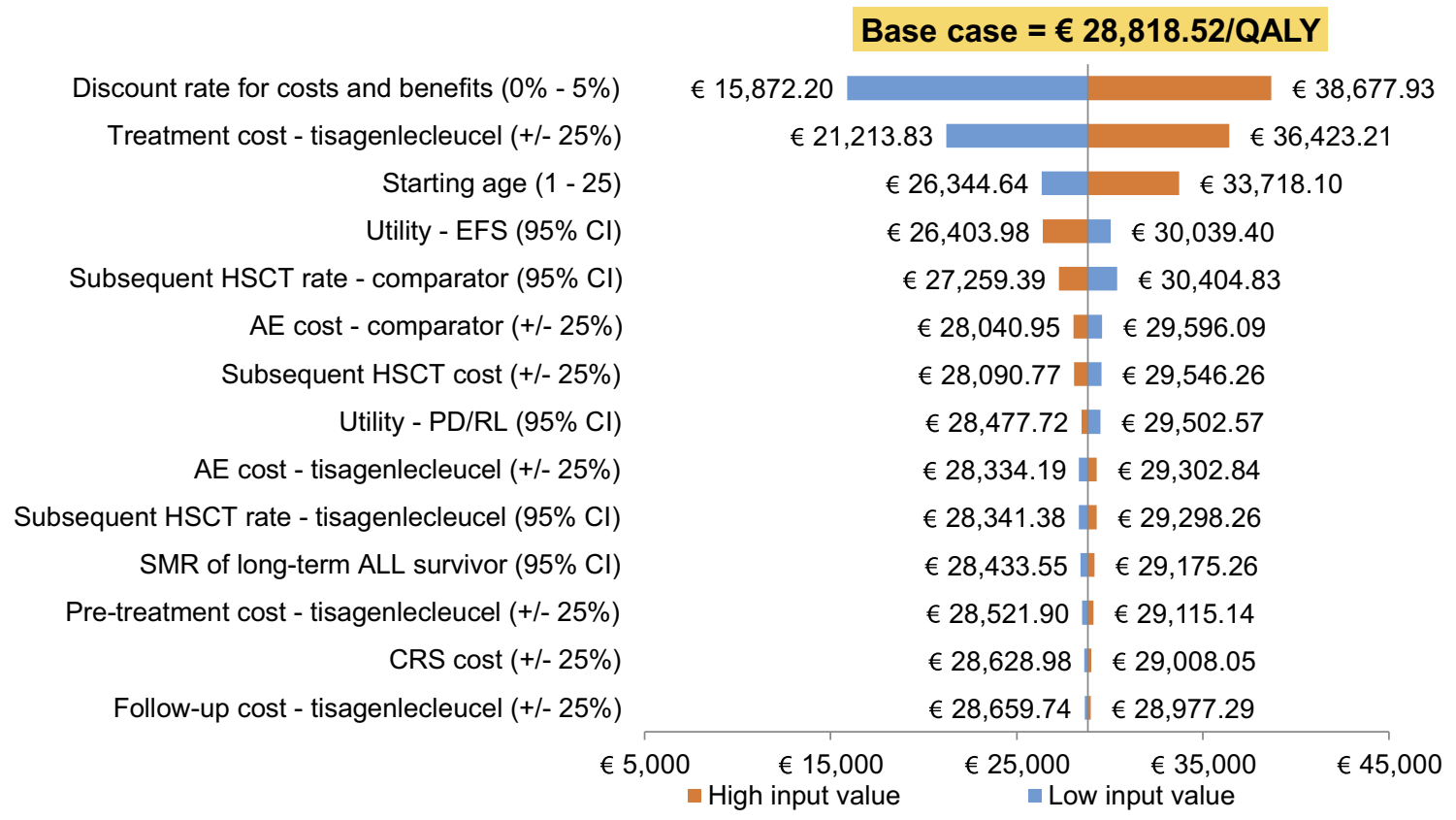

Figure 4 Results of the deterministic sensitivity analysis. Tornado diagram.

Abbreviations: AE, adverse event; ALL, acute lymphoblastic leukaemia; Cl, confidence interval; CRS, cytokine release syndrome; EFS, event-free survival; HSCT, haematopoietic stem cell transplantation; PD/RL, progressive/relapsed disease; QALY, quality-adjusted life-year; SMR, standardized mortality ratio

The present study has some limitations due to the limitations in the clinical trials on which it is based. The most important is the difficulty in establishing comparisons with other treatments and in estimating the long-term effectiveness results. Secondly, the follow-up of the studies of tisagenlecleucel is limited, which requires extrapolations of long-term efficacy. Clinical studies to determine the effectiveness of tisagenlecleucel in real life are needed. However, in the sensitivity analysis, the effect of variations in long-term modelling assumptions was evaluated in order to consider the patient's lifetime, and in no case did the results exceed $€ 50,000 / \mathrm{QALY}$, confirming the robustness of the results.

Another parameter influenced by the limitations in the follow-up of studies of tisagenlecleucel is the duration of IVIG treatment. Therefore, in the sensitivity analysis, a scenario was considered in which patients would receive IVIG while free of progression (compared with 11.4 months in the base case), resulting in an ICUR of $€ 38,247.21 /$ QALY. Therefore, even supposing that patients received IVIG during the entire remission period, tisagenlecleucel would be a cost-effective treatment option, taking into account the thresholds used in cost-effectiveness studies of orphan drugs, which can exceed $€ 100,000 /$ QALY. $^{49,50}$

The introduction of CAR-T therapies in the NHS poses important medical, logistical and economic challenges, but also offers opportunities to improve efficiency. Given the scarcity of data on the long-term effectiveness of treatments, the adoption of risk-sharing agreements or innovative pay-by-results schemes is a very useful option for managing uncertainty. The adoption of this type of agreements will reduce the costs associated with treatment with tisagenlecleucel and improve the efficiency of the management of children and young adults with r/r ALL.

\section{Conclusion}

The results of this study show a greater benefit for tisagenlecleucel vs salvage chemotherapy in the treatment of $r / r$ ALL in Spain. From the NHS perspective, tisagenlecleucel would represent a cost-effective intervention for the treatment of children and young adult patients with $\mathrm{r} / \mathrm{r}$ ALL.

\section{Author Contributions}

Each author of the present work affirms that:

- All authors contributed to data analysis, drafting or revising the article, gave final approval of the version to be published, and agree to be accountable for all aspects of the work.

- If requested, the authors will provide the data or will cooperate fully in obtaining and providing the data on which the manuscript is based for examination by the editors or their assignees. 


\section{Disclosure}

JMRS and $\mathrm{CDH}$ are, respectively, employed by Catalan Institute of Oncology-Hospital Germans Trias i Pujol and Hospital Universitari Vall d'Hebron. DML and NGM are employees of Oblikue Consulting, an independent contract health economic organization that received consultancy fees from Novartis Farmacéutica, S.A. to conduct this research. AAS and JG are employees of Novartis Farmacéutica, S.A., the marketing authorization holder for $\mathrm{Kymriah}^{\circledR}$ (tisagenlecleucel). JMRS reports grants and personal fees from AMGEN, Pfizer, Incyte, and Shire, and personal fees from Celgene, outside the submitted work. CHD reports personal fees and non-financial support from Novartis during the conduct of the study; and personal fees and non-financial support from Jazz Pharmaceuticals, Gilead, and Novartis, and non-financial support from Alexion, outside the submitted work. The funding body was not involved in the study design, collection and interpretation of the data, or the decision to publish. The authors report no other conflicts of interest in this work.

\section{References}

1. Coebergh JW, Reedijk AM, de Vries E, et al. Leukaemia incidence and survival in children and adolescents in Europe during 1978-1997. Report from the automated childhood cancer information system project. Eur J Cancer. 2006;42(13):2019-2036. doi:10.1016/j.ejca.2006. 06.005

2. Wartenberg D, Groves FD, Adelman AS, editors. Acute lymphoblastic leukemia: epidemiology and etiology. In: Acute Leukemias. Berlin: Springer; 2008:77-93. doi:10.1007/978-3-540-72304-2_5.

3. Hunger SP, Mullighan CG. Acute lymphoblastic leukemia in children. Longo DL, ed. N Engl J Med. 2015;373(16):1541-1552. doi:10.1056/ NEJMra1400972

4. Pui CH, Sandlund J, Pei D, et al. Improved outcome for children with acute lymphoblastic leukemia: results of total therapy study XIIIB at St Jude Children's Research Hospital. Blood. 2004;104(9):2690-2696. doi:10.1182/blood-2004-04-1616

5. Nguyen K, Devidas M, Cheng SC, et al. Factors influencing survival after relapse from acute lymphoblastic leukemia: a children's oncology group study. Leukemia. 2008;22(12):2142-2150. doi:10.1038/leu.2008.251

6. Reismüller B, Peters C, Dworzak MN, et al. Outcome of children and adolescents with a second or third relapse of acute lymphoblastic leukemia (ALL). J Pediatr Hematol Oncol. 2013;35(5):e200-e204. doi:10.1097/MPH.0b013e318290c3d6

7. Chessells JM, Veys P, Kempski H, et al. Long-term follow-up of relapsed childhood acute lymphoblastic leukaemia. $\mathrm{Br} J$ Haematol. 2003;123(3):396-405. doi:10.1046/j.1365-2141.2003.04584.x

8. Ceppi F, Duval M, Leclerc JM, et al. Improvement of the outcome of relapsed or refractory acute lymphoblastic leukemia in children using a risk-based treatment strategy. Mills K, ed. PLoS One. 2016;11(9): e0160310. doi:10.1371/journal.pone.0160310

9. Nietfeld JJ, Pasquini MC, Logan BR, Verter F, Horowitz MM. Lifetime probabilities of hematopoietic stem cell transplantation in the U.S. Biol Blood Marrow Transplant. 2008;14(3):316-322. doi:10.1016/j.bbmt.2007.12.493
10. Dini G, Zecca M, Balduzzi A, et al. No difference in outcome between children and adolescents transplanted for acute lymphoblastic leukemia in second remission. Blood. 2011;118(25):6683-6690. doi:10.1182/blood-2011-05-354233

11. Jacobsohn DA, Hewlett B, Ranalli M, Seshadri R, Duerst R, Kletzel M. Outcomes of unrelated cord blood transplants and allogeneicrelated hematopoietic stem cell transplants in children with highrisk acute lymphocytic leukemia. Bone Marrow Transplant. 2004;34 (10):901-907. doi:10.1038/sj.bmt.1704681

12. Mateos MK, O'Brien TA, Oswald C, et al. Transplant-related mortality following allogeneic hematopoeitic stem cell transplantation for pediatric acute lymphoblastic leukemia: 25-year retrospective review. Pediatr Blood Cancer. 2013;60(9):1520-1527. doi:10.1002/pbc.24559

13. Maude SL, Laetsch TW, Buechner J, et al. Tisagenlecleucel in children and young adults with c-cell lymphoblastic leukemia. $N$ Engl $J$ Med. 2018;378(5):439-448. doi:10.1056/NEJMoa1709866

14. European Medicines Agency (EMA). Kymriah: cells dispersion for infusion [summary of product characteristics]. Available from: https://www.ema.europa.eu/en/documents/product-information/kym riah-epar-product-information_en.pdf. Accessed March 7, 2019.

15. Agencia Española de Medicamentos y Productos Sanitarios (AEMPS). Informe de Posicionamiento Terapéutico de Tisagenlecleucel $\left(\mathrm{Kymriah}^{\circledR}\right)$ [Therapeutic Positioning Report of Tisagenlecleucel]. Madrid; 2019. Available from: https://www. aemps.gob.es/medicamentosUsoHumano/informesPublicos/docs/IPTtisagenlecleucel-kymriah-LAL-LCGB.pdf. Accessed March 4, 2019.

16. ClinicalTrials.gov. Determine efficacy and safety of CTL019 in pediatric patients with relapsed and refractory B-cell ALL (ELIANA). Available from: https://clinicaltrials.gov/ct2/show/ NCT02435849. Accessed February 13, 2019.

17. ClinicalTrials.gov. Study of efficacy and safety of CTL019 in pediatric ALL patients. Available from: https://clinicaltrials.gov/ct $2 /$ show/ NCT02228096. Accessed February 13, 2019.

18. ClinicalTrials.gov. Phase I/IIA study of CART19 cells for patients with chemotherapy resistant or refractory CD19+ leukemia and lymphoma (Pedi CART19). Available from: https://clinicaltrials.gov/ct2/ show/NCT01626495. Accessed February 13, 2019.

19. European Medicines Agency (EMA). Kymriah (EPAR) [summary of product characteristics]. Available from: www.ema.europa.eu/en/ documents/assessment-report/kymriah-epar-public-assessmentreport_en.pdf. Accessed March 7, 2019.

20. López Bastida J, Oliva J, Antoñanzas F, et al. Propuesta de guía para la evaluación económica aplicada a las tecnologías sanitarias [A proposed guideline for economic evaluation of health technologies]. Gac Sanit. 2010;24(2):154-170. doi:10.1016/j.gaceta.2009.07.011

21. Ortega A, Marín R, Fraga MD, López-Briz E, Puigventós F. Guía de evaluación económica e impacto presupuestario en los informes de evaluación de medicamentos: guía práctica [Economic evaluation and budgetary impact guidelines for assessment reports on medicinal products]. Available from: https://gruposdetrabajo.sefh.es/genesis/gen esis/Documents/GUIA_EE_IP_GENESIS-SEFH_19_01_2017.pdf. Accessed February 25, 2019.

22. Von Stackelberg A, Völzke E, Kühl JS, et al. Outcome of children and adolescents with relapsed acute lymphoblastic leukaemia and non-response to salvage protocol therapy: a retrospective analysis of the ALL-REZ BFM study group. Eur J Cancer. 2011;47(1):9097. doi:10.1016/j.ejca.2010.09.020

23. MacArthur AC, Spinelli JJ, Rogers PC, Goddard KJ, Abanto ZU, McBride ML. Mortality among 5-year survivors of cancer diagnosed during childhood or adolescence in British Columbia, Canada. Pediatr Blood Cancer. 2007;48(4):460-467. doi:10.1002/ pbc. 20922

24. Instituto Nacional de Estadística (INE). Instituto Nacional de Estadística [homepage on the internet]. Available from: http://www. ine.es. Accessed February 25, 2019. 
25. Kelly MJ, Pauker SG, Parsons SK. Using nonrandomized studies to inform complex clinical decisions: the thorny issue of cranial radiation therapy for T-cell acute lymphoblastic leukemia. Pediatr Blood Cancer. 2015;62(5):790-797. doi:10.1002/pbc.25451

26. Sung L, Buckstein R, Doyle JJ, Crump M, Detsky AS. Treatment options for patients with acute myeloid leukemia with a matched sibling donor: a decision analysis. Cancer. 2003;97(3):592-600. doi:10.1002/cncr. 11098

27. Szende A, Janssen B, Cabases J, eds. Self-Reported Population Health: An International Perspective Based on EQ-5D. Dordrecht: Springer; 2014.

28. Jefatura del Estado (Spain). Real Decreto-ley (RDL) 8/2010, de 20 de mayo, por el que se adoptan medidas extraordinarias para la reducción del déficit público. Boletín Oficial del Estado. Núm. 126. Sec. I. Pág. 45070. Lunes 24 de mayo de 2010. [Updated 2010]. Available from: https://www.boe.es/boe/dias/2010/05/24/pdfs/BOEA-2010-8228.pdf. Accessed March 6, 2019.

29. CGCOF. Bot PLUS 2.0 [homepage on the Internet]. Base de datos del Consejo General de Colegios Oficiales de Farmacéuticos [General council of the association of official pharmacists database]. Available from: https://botplusweb.portalfarma.com/. Accessed March 19, 2019.

30. Nuño-Solinís R, Herrera Molina E, Librada Flores S, Orueta Mendía JF, Cabrera-León A. Actividad asistencial y costes en los últimos 3 meses de vida de pacientes fallecidos con cáncer en Euskadi [Care costs and activity in the last three months of life of cancer patients who died in the Basque Country (Spain)]. Gac Sanit. 2017;31 (6):524-530. doi:10.1016/j.gaceta.2016.06.005

31. Ministerio de Sanidad, Servicios Sociales e Igualdad. Conjunto Mínimo Básico de Datos al alta hospitalaria [Basic minimum dataset of hospital discharge] [homepage on the internet]. Available from: http://pestadistico.inteligenciadegestion.msssi.es/publicosns. Accessed May 23, 2018

32. Gisbert R, Brosa M eSalud: infomación económica del sector sanitario [webpage on the Internet] [eSalud: economic information of the health sector]. Barcelona: oblikue consulting, S.L, 2018. Available from: http://oblikue.com/bddcostes. Accessed July 22, 2019.

33. Raetz EA, Borowitz MJ, Devidas M, et al. Reinduction platform for children with first marrow relapse of acute lymphoblastic leukemia: a children's oncology group study. J Clin Oncol. 2008;26(24):3971-3978. doi:10.1200/JCO.2008.16.1414

34. Maude SL, Grupp SA, Pulsipher MA, et al. Analysis of safety data from 2 multicenter trials of CTL019 in pediatric and young adult patients with relapsed/refractory (R/R) B-cell acute lymphoblastic leukemia (B-ALL). European Hematology Association; 2017. Available at: https://library. ehaweb.org/eha/2017/22nd/181804/.

35. Ministerio de Sanidad Consumo y Bienestar Social. Nota informativa de la reunión de la comisión interministerial de precios de los medicamentos. [Informative note of the meeting from the Spanish interministerial medicinal products pricing committee]. Sesión 187. [Updated 2018]. Available from: https://www.mscbs. gob.es/profesionales/farmacia/pdf/NOTA_INFORMATIVA_DE_ LA CIPM 187 web.pdf. Accessed February 24, 2020.

36. Sarkar RR, Gloude NJ, Schiff D, Murphy JD. Cost-effectiveness of chimeric antigen receptor T-cell therapy in pediatric relapsed/refractory B-cell acute lymphoblastic leukemia. J Natl Cancer Inst. 2018;111(7):719-726. doi:10.1093/jnci/djy193

37. Whittington MD, McQueen RB, Ollendorf DA, et al. Long-term survival and value of chimeric antigen receptor T-cell therapy for pediatric patients with relapsed or refractory leukemia. JAMA Pediatr. 2018;172 (12):1161-1168. doi:10.1001/jamapediatrics.2018.2530

38. Lin JK, Lerman BJ, Barnes JI, et al. Cost effectiveness of chimeric antigen receptor $\mathrm{T}$-cell therapy in relapsed or refractory pediatric B-cell acute lymphoblastic leukemia. J Clin Oncol. 2018; In press. doi:10.1200/JCO.2018.79.0642
39. National Institute for Health and Care Excellence (NICE) Tisagenlecleucel for treating relapsed or refractory B-cell acute lymphoblastic leukaemia in people aged up to 25 years: technology appraisal guidance. Available from: https://www.nice.org.uk/gui dance/ta554/resources/tisagenlecleucel-for-treating-relapsed-or-refrac tory-bcell-acute-lymphoblastic-leukaemia-in-people-aged-up-to-25years-pdf-82607021872837. Accessed May 31, 2019.

40. Institute for Clinical and Economic Review (ICER). Chimeric antigen receptor T-cell therapy for B-cell cancers: effectiveness and value: final evidence report. Available from: https://icer-review.org/ wp-content/uploads/2017/07/ICER_CAR_T_Final_Evidence Report 032318.pdf. Accessed March 4, 2019.

41. Sacristán JA, Oliva J, Del Llano J, Prieto L, Pinto JL. ¿Qué es una tecnología sanitaria eficiente en España? [What is an efficient health technology in Spain?]. Gac Sanit. 2002;16(4):334-343. doi:10.1016/ S0213-9111(02)71933-X

42. Agencia Española de Medicamentos y Productos Sanitarios (AEMPS). Informe de Posicionamiento Terapéutico de Blinatumomab (Blincyto ${ }^{\circledR}$ ) [Therapeutic positioning report of blinatumomab]. Madrid; 2017. Available from: https://www.aemps.gob.es/medicamentosUsoHumano/ informesPublicos/docs/IPT-blinatumomab-Blincyto-LAL.pdf. Accessed March 14, 2019.

43. Ministerio de Sanidad Consumo y Bienestar Social. Nota informativa de la reunión de la Comisión Interministerial de Precios de los Medicamentos [Informative note of the meeting from the Spanish interministerial medicinal products pricing committee]. Sesión 190. [Updated 2019]. Available from: https://www.mscbs.gob.es/va/profesionales/farmacia/pdf/NOTA INFORMATIVA_DE_LA_CIPM_190_web.pdf. Accessed June $11,2019$.

44. Food and Drug Administration (FDA). Highlights of prescribing information: BLINCYTO ${ }^{\circledR}$ (blinatumomab) for injection, for intravenous use Initial U.S: approval; 2014. Available from: https://www. accessdata.fda.gov/drugsatfda_docs/label/2018/125557s013lbl.pdf. Accessed March 7, 2019.

45. Brown PA, Ji L, Xu X, et al. A randomized phase 3 trial of blinatumomab vs. chemotherapy as post-reinduction therapy in High and Intermediate Risk (HR/IR) first relapse of B-Acute Lymphoblastic Leukemia (B-ALL) in Children and Adolescents/Young Adults (AYAs) demonstrates superior Eff. Blood. 2019;134(Supplement_2):LBA-1-LBA-1. doi:10.1182/ blood-2019-132435

46. Von Stackelberg A, Locatelli F, Zugmaier G, et al. Phase I/Phase II study of blinatumomab in pediatric patients with relapsed/refractory acute lymphoblastic leukemia. J Clin Oncol. 2016;34(36):43814389. doi:10.1200/JCO.2016.67.3301

47. Locatelli F, Zugmaier G, Bader P, et al. Blinatumomab in pediatric patients with relapsed/refractory B-cell precursor and molecularly Resistant Acute Lymphoblastic Leukemia (R/R ALL): updated analysis of 110 patients treated in an expanded access study (RIALTO). Blood. 2019;134(Supplement 1):1294. doi:10.1182/blood-2019-121615

48. Jeha S, Razzouk B, Rytting M, et al. Phase II study of clofarabine in pediatric patients with refractory or relapsed acute myeloid leukemia. $J$ Clin Oncol. 2009;27(26):4392-4397. doi:10.1200/JCO.2008.18.8706

49. Brosa M, García Del Muro X, Mora J, et al. Orphan drugs revisited: costeffectiveness analysis of the addition of mifamurtide to the conventional treatment of osteosarcoma. Expert Rev Pharmacoecon Outcomes Res. 2015;15(2):331-340. doi:10.1586/14737167.2015.972378

50. Núñez M, Gil B, Sacristán J, Dilla T. Analysis of orphan drugs marketed in Spain during the period 2010-2015: epidemiological, clinical and economic characteristics. Heal Econ Outcome Res. 2017;3(3):1-10. doi:10.4172/2471-268X.1000140 


\section{Publish your work in this journal}

ClinicoEconomics and Outcomes Research is an international, peerreviewed open-access journal focusing on Health Technology Assessment, Pharmacoeconomics and Outcomes Research in the areas of diagnosis, medical devices, and clinical, surgical and pharmacological intervention. The economic impact of health policy and health systems organization also constitute important areas of coverage. The manuscript management system is completely online and includes a very quick and fair peer-review system, which is all easy to use. Visit http://www.dovepress.com/testimonials.php to read real quotes from published authors.

Submit your manuscript here: https:/www.dovepress.com/clinicoeconomics-and-outcomes-research-journal 